\title{
EDUKASI GIZI PADA MASYARAKAT DALAM MENINGKATKAN PENGETAHUAN TENTANG GIZI
}

\author{
Hanik Machfudloh $^{1 *}$, Paramitha Amelia Kusumawardani ${ }^{1}$, Lukman Hudi², A. \\ Miftakhurrahmat ${ }^{3}$ \\ ${ }^{1}$ Fakultas Ilmu Kesehatan, Universitas Muhammadiyah Sidoarjo \\ ${ }^{2}$ Fakultas Sains dan Teknologi Universitas Muhammadiyah Sidoarjo \\ ${ }^{3}$ Fakultas Sains dan teknologi, Universitas Muhammadiyah Sidoarjo \\ *Email: hanikkebidanan@gmail.com
}

\begin{tabular}{|c|c|}
\hline Informasi Artikel & Abstrak \\
\hline $\begin{array}{l}\text { Diterima: 09-06-2021 } \\
\text { Disetujui: 11-07-2021 } \\
\text { Dipublikasikan: 14-07- } \\
2021\end{array}$ & $\begin{array}{l}\text { Dinegara berkembang, adanya transisi gizi membuat prevalensi gizi } \\
\text { meningkat sehingga mengalami beban ganda untuk masalah gizi dimana } \\
\text { gizi yang kurang maupun lebih dapat menganggu proses pertumbuhan dan } \\
\text { perkembangan terutama pada anak serta dapat meningkatkan risiko } \\
\text { penyakit pada anak maupun orang dewasa. Survey pendahuluan di Desa } \\
\text { Sidokepung kecamatan Buduran Kabupaten Sidoarjo, masih terdapat balita } \\
\text { gizi kurang sehingga tim pengabdi mengadakan edukasi mengenai gizi } \\
\text { yang melibatkan para pembudidaya ikan lele dan masyarakat umumnya. } \\
\text { Metode yang dilaksanakan dalam kegiatan pengabdian masyarakat ini } \\
\text { dengan ceramah, kunjungan, dan demo langsung. Kegiatan ceramah dan } \\
\text { kunjungan dilakukan untuk pemahaman materi gizi seimbang sedangkan } \\
\text { demo langsung dilakukan untuk meningkatkan ketrampilan tentang } \\
\text { penerapan gizi seimbang sehingga dapat diterapkan dalam pemberian } \\
\text { makanan sehari-hari yang bergizi seimbang. Hasil dari kegiatan pengabdian } \\
\text { masyarakat adalah meningkatnya pemahaman dari peserta edukasi tentang } \\
\text { gizi seimbang dari 55\% menjadi 92\% sehingga masyarakat cukup tertarik } \\
\text { pada masalah yang disajikan. Selain itu, terdapat peningkatan kesadaran } \\
\text { dari } 66 \% \text { menjadi 89\% tentang gizi seimbang yang merupakan keharusan } \\
\text { dan kewajiban setiap keluarga apalagi didukung dengan sebagian besar } \\
\text { masyarakat merupakan peternak budidaya ikan lele. Hal ini menunjukkan } \\
\text { bahwa pentingnya edukasi tentang gizi seimbang kepada masyarakat } \\
\text { terutama ibu yang mempunyai anak balita. } \\
\text { Abstract }\end{array}$ \\
\hline $\begin{array}{l}\text { Keywords : } \\
\text { Education, Nutrition, } \\
\text { Health, Catfish farming, } \\
\text { Stunting }\end{array}$ & $\begin{array}{l}\text { In developing countries, nutritional transition makes prevalence of nutrition } \\
\text { increase so that it experiences a double burden for nutritional problems } \\
\text { where less or more nutrition can disrupt the process of growth and } \\
\text { development, especially in children and can increase the risk of disease in } \\
\text { children and adults. Preliminary survey in Sidokepung Village, Buduran } \\
\text { District, Sidoarjo Regency, there are still malnourished toddler, so the } \\
\text { service team held education about nutrition involving catfish cultivators and } \\
\text { general public. Method implemented in this community service activity is } \\
\text { with lectures, visits, and live demos. Lectures and visits were conducted to }\end{array}$ \\
\hline
\end{tabular}


understand material on balanced nutrition, while live demonstrations were conducted to improve skills on the application of balanced nutrition so that it can be applied in the provision of a balanced daily diet. The result of community service activities is an increase in understanding of education participants about balanced nutrition from $55 \%$ to $92 \%$ so that people are quite interested in problems presented. In addition, there was an increase in awareness from $66 \%$ to $89 \%$ about balanced nutrition which is a must and obligation for every family, especially when majority of community are catfish farmers. This shows that importance of education about balanced nutrition to community, especially mothers who have toddler.

\section{PENDAHULUAN}

Pengertian dari sehat adalah tidak adanya gangguan terhadap jasmani, rohani dan sosial sehingga dapat disebut juga dengan pribadi dari seseorang seutuhnya yang meliputi sehat secara fisik, mental dan sosial (Nelwan dan Sumampouw 2019). Pemahaman dari sehat tersebut sudah sesuai dengan pengertian sehat yang disampaikan WHO yaitu " keadaan yang meliputi kesehatan fisik, kesehatan mental, dan kesehatan sosial dan bukan hanya keadaan bebas dari penyakit, cacat, dan kelemahan.”. Jadi masyarakat tidak hanya cukup bebas dari suatu penyakit, tetapi juga harus meliputi secara keseluruhan, yaitu sehat secara total sehingga untuk dapat mencapainya, masyarakat perlu diberikan pendidikan kesehatan yang sistematis dan akan membekali mereka didalam kehidupannya dan dalam sikap hidup seharihari (Kemenkes RI 2014).

Susunan pangan sehari-hari yang mengandung zat-zat gizi dalam jenis dan jumlah yang sesuai dengan kebutuhan tubuh, dengan cara memperhatikan prinsip keanekaragaman pangan, aktivitas fisik, perilaku hidup bersih dan sehat, dan dapat mempertahankan berat badan normal (tidak terlalu kurus dan tidak terlalu gemuk) untuk dapat mencegah masalah gizi (Kemenkes RI 2018). Sekarang ini sebagian besar dari penduduk Indonesia dapat dinyatakan tidak sakit namun juga tidak sehat sehingga umumnya disebut kekurangan gizi. Kekurangan gizi sering terlewatkan dari pengamatan, namun dapat secara perlahan mempunyai dampak pada tingginya angka kematian ibu, angka kematian pada bayi, angka kematian pada balita, serta rendahnya umur untuk harapan hidup (Amalia Fifiantyas 2018).

Dibeberapa negara berkembang, prevalensi gizi meningkat dikarenakan adanya transisi gizi sehingga memicu beberapa negara tersebut mengalami beban ganda untuk masalah gizi yaitu masalah gizi yang kurang dan masalah gizi lebih (Gea 2019). Baik gizi yang kurang maupun gizi yang lebih mampu menganggu pada proses pertumbuhan dan perkembangan terutama pada anak dan dapat meningkatkan risiko penyakit-penyakit (Kemenkes RI, 2018). 
Provinsi Jawa Timur salah satu provinsi yang menjadi wilayah prioritas dalam penanganan tentang masalah stunting didasarkan data dari Bappenas selama tahun 20182019. Tahun 2018 provinsi Jawa Timur mempunyai 11 daerah untuk penanggulangan masalah stunting dan pada tahun 2019 bertambah 1 kabupaten sehingga Jawa Timur mempunyai 12 daerah untuk penanggulangan stunting (Dinas Kesehatan 2019). Upaya penurunan angka stunting dilakukan melalui dua pendekatan, yaitu dengan melakukan pendekatan gizi spesifik untuk mengatasi dari penyebab langsung stunting dan melakukan pendekatan gizi yang sensitif dalam mengatasi penyebab tidak langsung (Directorate of Community Nutrition of The Ministry of Health of The Republic of Indonesia. 2017).

Data pada survey pendahuluan di Desa Sidokepung kecamatan Buduran Kabupaten Sidoarjo, masih terdapat anak balita yang berjumlah 7 balita yang memiliki gizi kurang dan mengkonsumsi makanan yang kurang bergizi. Sebagian besar makanan yang mereka konsumsi adalah makanan instan dan tidak memperhatikan dengan prinsip gizi seimbang, tidak ada sayuran dan tidak menyukai ikan padahal di desa Sidokepung ini sebagian besar orang tua sebagai pembudidaya ikan lele. Ikan lele merupakan ikan air tawar yang mempunyai gizi yang baik dan protein yang tinggi(Amelia, Paramitha; Jakaria Bamban 2018) . Dari data dan beberapa penjelasan di atas maka tim pengabdi mempunyai kegiatan dalam menjalankan salah satu darmanya dimana harus melaksanakan pengabdian kepada masyarakat turut serta dalam penyuluhan kesehatan gizi kepada masyarakat maka tim pengabdi mengadakan edukasi mengenai gizi pada masyarakat yang melibatkan para peternak budidaya ikan lele dan masyarakat umumnya.

\section{METODE}

Kegiatan awal yang dilaksanakan dalam Pengabdian kepada Masyarakat ini dengan melaksanakan kunjungan ke lapangan, melihat secara langsung keadaan dan permasalahan yang dihadapi mitra. Selanjutnya setelah PKM ini mendapatkan persetujuan, maka tim pengabdi melakukan diskusi dengan mitra (pembudidaya ikan lele) untuk membuat kegiatan-kegiatan yang merupakan solusi permasalahan. Masing-masing dari kegiatan mempunyai PIC. Kegiatan ceramah dan kunjungan dilakukan pada masyarakat terutama ibuibu yang mempunyai anak balita dengan materi kegiatan tentang kesehatan dan gizi seimbang. Kegiatan ini dilakukan selama 1 bulan dengan 4 kali kegiatan (kegiatan ceramah 2 kali dan kunjungan dari rumah ke rumah ibu yang mempunyai balita sebanyak $2 \mathrm{x}$ ), selain kegiatan tersebut, dilakukan kegiatan demonstrasi untuk contoh gizi seimbang yang dapat 
diberikan dan dikonsumsi oleh anak-anak terutama pada balita. Kegiatan ini dilakukan selama 1 bulan dengan 2x kegiatan. Evaluasi dari kegiatan dilakukan setelah kegiatan ceramah, kunjungan rumah dan demonstrasi selesai dilakukan. Selama pelaksanaan pengabdian masyarakat, tim pengabdi selalu melakukan koordinasi dengan mitra sehingga dalam proses pelaksanaan mitra dapat memahami dan menjalankan secara mandiri. Potensi masing-masing tim pengabdi dapat dioptimalkan sesuai dengan bidang kepakarannya sehingga hubungan mitra dengan tim pengabdi adalah mitra mempunyai kontribusi dalam memberikan gambaran permasalahan sehingga tim pengabdi menawarkan solusi yang akan memberikan manfaat bagi mitra.

Metode yang dilaksanakan dalam kegiatan pengabdian masyarakat ini yaitu dengan ceramah, kunjungan, dan demo langsung. Kegiatan ceramah dan kunjungan dilakukan untuk pemahaman tentang materi kesehatan dan gizi dengan tujuan masyarakat (kader posyandu, pembudidaya lele) dan terutama ibu-ibu yang mempunyai anak balita dapat meningkatkan pengetahuan sehingga dapat mencegah kurang gizi pada anak dan menjelaskan tentang cara budidaya lele yang baik sehingga gizi yang terkandung dalam ikan lele bisa maksimal. Sasaran kegiatan ceramah dan kunjungan ini adalah masyarakat terutama ibu-ibu yang mempunyai anak balita dan pembudidaya lele (Sinuhaji 2018). Sedangkan kegiatan demo langsung dilakukan untuk aplikasi materi yang langsung dapat ditiru dan dirasakan oleh masyarakat, kegiatan ini mempunyai tujuan untuk meningkatkan ketrampilan tentang penerapan gizi seimbang sehingga dapat diterapkan dalam pemberian makanan sehari-hari yang bergizi seimbang. Metode ceramah yang dilaksanakan dalam bentuk penjelasan langsung oleh narasumber yaitu tim pengabdi dari bidang kesehatan (Bu Hanik dan $\mathrm{Bu}$ Paramitha) yang menjelaskan tentang gizi seimbang sedangkan tim pengabdi dari bidang pertanian menjelaskan tentang cara budidaya lele yang baik. Media yang digunakan adalah leaflet dan dilaksanakan melalui fanel forum yang dihadiri sebanyak 15 orang peserta yang terdiri dari kader Posyandu, ibu-ibu yang mempunyai anak balita dan pembudidaya ikan lele di desa Sidokepung Kecamatan Buduran Kabupaten Sidoarjo. Sedangkan metode kunjungan langsung, dilaksanakan oleh tim pengabdi kepada kepala keluarga yang dianggap mempunyai masalah dalam kesehatan dan gizi. Kegiatan demontrasi dilakukan oleh tim pengabdi dari bidang kesehatan untuk mendemontrasikan secara langsung cara membuat makanan yang memenuhi kaidah gizi seimbang untuk diterapkan pada anak-anak terutama anak balita dan makanan yang bisa dibuat dengan menggunakan bahan ikan lele. 


\section{HASIL DAN PEMBAHASAN}

Hasil dari kegiatan pengabdian masyarakat yang dilaksanakan adalah dalam bentuk pemahaman dari peserta edukasi tentang kesehatan dan gizi seimbang yang menjadi bahan ceramah. Berdasarkan hasil dari pemantauan selama proses kegiatan pengabdian ini berlangsung diperoleh kesan masyarakat cukup tertarik pada masalah yang disajikan dalam kegiatan ini. Hal ini diperkuat dengan peserta edukasi antusias dengan bertanya kepada narasumber tentang masalah-masalah gizi seimbang. Selain itu, para peserta memahami dengan baik tentang materi yang diberikan narasumber, terlihat dari pertanyaan yang muncul dan keaktifan pada waktu kegiatan maupun jawaban dari para peserta. Sedangkan dilihat dari kuesioner yang disebarkan ke peserta, terdapat peningkatan pemahaman dari peserta edukasi tentang gizi seimbang dari 55\% menjadi 92\%, bahkan mereka berpendapat setelah diberikan edukasi mereka sadar bahwa memperhatikan tentang gizi seimbang merupakan keharusan dan kewajiban setiap keluarga apalagi didukung dengan sebagian besar masyarakat merupakan peternak budidaya ikan lele dimana ikan lele merupakan ikan yang tinggi protein dengan tingkat kesadaran dari $66 \%$ meningkat menjadi $89 \%$.

Kader berkomitmen untuk melakukan pemantauan terhadap kesehatan dan gizi pada masyarakat, mengingatkan masyarakat, dan memberi contoh langsung pada mereka. Pola konsumtif yang sudah merasuki setiap keluarga, terkadang sulit untuk mengontrol kesehatan mereka. Misalnya anak-anak mereka jajan makanan yang jelas lebih banyak menimbulkan penyakit daripada sehat, tapi itu tak dapat dihindari, sebab pola makan anak sudah berbeda dengan yang dikehendaki teori. Oleh karena itu, kader posyandu bersama dengan perangkat desa tetap melakukan pemantauan secara intens.

Berdasarkan evaluasi yang dilakukan tim pengabdi bersama dengan kader posyandu dan perangkat desa, masyarakat terutama ibu-ibu yang mempunyai anak balita sudah memberikan gizi seimbang yang benar untuk anak balitanya, sedangkan pembudidaya ikan lele juga sudah menerapkan cara-cara budidaya ikan lele yang baik. 

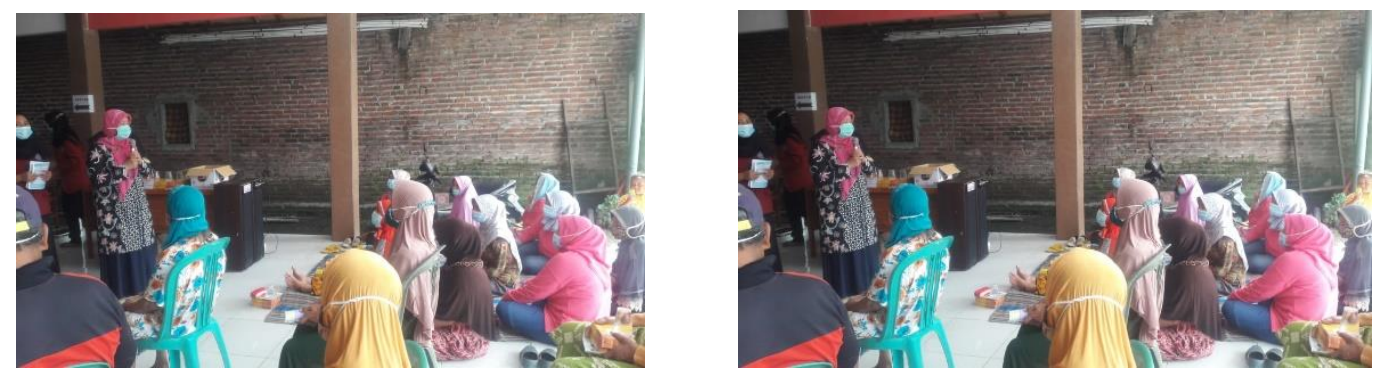

Gambar. Edukasi dengan metode ceramah pada peserta

\section{KESIMPULAN}

- Meningkatnya pemahaman dari peserta edukasi tentang gizi seimbang dari 55\% menjadi $92 \%$

- Terdapat peningkatan kesadaran dari $66 \%$ menjadi $89 \%$ setelah diberikan edukasi tentang gizi seimbang.

- Pentinya edukasi tentang gizi seimbang kepada masyarakat terutama ibu-ibu yang memiliki anak balita dan kader posyandu serta pembudidaya ikan lele sebagai ikan yang tinggi akan protein.

\section{UCAPAN TERIMAKASIH}

Terima kasih kepada Direktorat Penelitian dan Pengabdian Masyarakat Universitas Muhammadiyah Sidoarjo yang telah memberikan dukungan financial terhadap pengabdian ini.

\section{DAFTAR PUSTAKA}

Amalia Fifiantyas. 2018. "Pengaruh Edukasi Gizi Terhadap Pengetahuan Dan Praktik Calon Ibu Dalam Pencegahan KEK Ibu Hamil.” 6(5):77.

Amelia, Paramitha; Jakaria Bamban, Ribangun. 2018. "PKM Pelaku Usaha Ikan Lele Jawa Timur." E-jurnal Universitas Muhammadiyah Malang 15.

Dinas Kesehatan. 2019. "Profil Kesehatan Jawa Timur 2018."

Directorate of Community Nutrition of The Ministry of Health of The Republic of Indonesia. 2017.

"the 2017 Indonesia Nutritional Status Monitoring (Pemantauan Status Gizi 2017)."

Gea, Aprilyani. 2019. "Pengaruh Penyuluhan Gizi Tentang Pola Makan Gizi Seimbang Dengan

Media Leaflet Terhadap Pengetahuan dan Tindakan Ibu Anak Paud Yang Stunting Di Desa

Sekip Kecamatan Lubuk Pakam.” Skripsi.

Kemenkes RI. 2014. Pedoman Gizi Seimbang Kementerian Kesehatan RI 2014.

Kemenkes RI. 2018a. Buletin Stunting. Kementerian Kesehatan. Republik Indonesia.

Kemenkes RI. 2018b. RISET KESEHATAN DASAR. 
Jurnal Abadimas Adi Buana

Vol. 5 No. $01(2021)$

e-ISSN : 2622-5719 | p-ISSN : 2622-5700

Nelwan, Jeini Ester, dan Oksfriani Sumampouw. 2019. "Pengaruh Penyuluhan Kesehatan Terhadap Perubahan.” jurnal PHWB 1(2).

Sinuhaji, Lidya Natalia Br. 2018. "Efektifitas Penyuluan Dan Media Leaflet Terhadap Pengetahuan Dan Sikap Ibu Balita Tentang Gizi Buruk Di Dusun Vii Desa Bangun Rejo Kecamatan Tanjung Morawa Utara." 